DOI: $10.19195 / 0524-4544.321 .11$

\title{
ANDRZEJ PASEK
}

Uniwersytet Wrocławski

andrzej.pasek@uwr.edu.pl

\section{Konstrukcja stanu wyższej konieczności w projekcie polskiego kodeksu karnego z 1932 roku}

„Jedną z podstaw niepoczytania za winę czynów, będących pogwałceniem obowiązującej ustawy karnej, może być tzw. konieczność wyższa, której pojęcie zostało, na ogół mówiąc, o wiele mniej naukowo wyjaśnione, niż pokrewne pojęcie obrony koniecznej. Konieczność wyższa miewa miejsce wtedy, gdy jakieś niebezpieczeństwo zagraża czyimś dobrom, będącym pod opieką prawa i niepodobna utraty ich uniknąć w inny sposób, jak przez wtargnięcie i pogwałcenie dóbr prawnych innej osoby. Dla ocalenia własnego dobra zostaje wówczas poświęcone dobro obce. Zachodzi więc w tych razach kolizja interesów, która ulega rozstrzygnięciu na korzyść własnego, ze szkodą zaś cudzego"1.

Pojęcie wyższej konieczności od dawna znane było nauce prawa i ustawodawstwu. Było ono obecne w starożytnym ustawodawstwie rzymskim, następnie w prawie kanonicznym, u pisarzy włoskich począwszy od XV w. oraz w niemieckiej Carolinie. Uzasadnienie wyższej konieczności oparte było z jednej strony na czynniku subiektywnym, tj. stanie psychicznym człowieka spowodowanym zagrażającym mu złem i koniecznością wyboru pomiędzy własną a cudzą szkodą, zaś z drugiej strony - na czynniku obiektywnym, tj. na uznaniu zgodności $\mathrm{z}$ prawem przeniesienia w pewnych warunkach zła $\mathrm{z}$ jednego podmiotu na drugi, obu korzystających jednak z ochrony obowiązującego prawa. Od obrony koniecznej różniła się zatem wyższa konieczność tym, że celem pierwszej była ochrona prawa przeciwko nieprawnemu na nie zamachowi, drugiej zaś obrona własnego prawa kosztem praw innej osoby ${ }^{2}$.

1 W.M. Borowski, Zasady prawa karnego, t. I. Część ogólna, Poznań 1922, s. 137.

2 Ibidem, s. 137-138. 
Juliusz Makarewicz, główny referent polskiego kodeksu karnego z 1932 r., stwierdził w jednym ze swoich wcześniejszych opracowań, że bezkarność poświęcenia dobra obcego dla ratowania dobra własnego tłumaczyć można tylko uwzględnieniem wyjątkowej sytuacji zagrożonego, spowodowanej stanem psychicznym wynikającym $\mathrm{z}$ wrodzonego człowiekowi instynktu samozachowawczego, z którym musi się liczyć także prawo. Według Makarewicza z powodu uwzględnienia tego czynnika psychicznego, w szeregu ustaw karnych brak samoistnej konstrukcji wyższej karalności, zastappionej pojęciem przymusu nieodpornego. Ujęcie to lwowski profesor oceniał jako „zbyt ciasne”, ponieważ wykluczało przypadki poświęcania cudzych dóbr majątkowych w celu ratowania własnych. Konsekwencją było wprowadzenie obok przymusu właściwego wywołanego między innymi groźbą, także wszelkich innych czynników wywołujących niebezpieczeństwo dla dóbr prawnych a oddziałujących na wolę sprawcy. Stan wyższej konieczności polega więc na bezkarności poświęcenia jednego dobra prawnego dla ratowania drugiego ze stanu niebezpieczeństwa ${ }^{3}$. Z faktu, że ratowanie to odbywa się kosztem dóbr prawnych osoby trzeciej, która niczym do wywołania owego niebezpieczeństwa się nie przyczyniła, wynikać muszą — pisał Makarewicz ograniczenia stosowania tej konstrukcji. Przede wszystkim poświęcenie cudzego dobra musi mieć charakter subsydiarny; „tylko w takim razie do tak radykalnego środka uciekać się można, kiedy nie ma żadnego innego sposobu wydobycia się z trudnej sytuacji. Nadto nie można poświęcać dobra wyższego rzędu (a więc inaczej niż przy obronie koniecznej); zasadą musi być proporcjonalność"4 ${ }^{\text {. Cho- }}$ dzi o uwzględnienie okoliczności wyjątkowo nieskutkującej wymierzeniem kary mimo oczywistej bezprawności działania; dlatego, według Makarewicza, można mówić o stanie wyższej konieczności, gdy osoba ratująca sama znajdowała się w krytycznej sytuacji. Nie można rozszerzać tego pojęcia na osoby trzecie, nie zainteresowane bezpośrednio ${ }^{5}$. Uczony dostrzegał wprowadzanie w nowym ustawodawstwie ogólnego prawa „pomocy koniecznej” udzielanej każdej osobie znajdującej się w niebezpieczeństwie. Nie sposób było uzasadnić go czynnikiem psychologicznym; instynktem samozachowawczym nawet w szerokim rozumie-

3 J. Makarewicz, Prawo karne ogólne, Kraków 1914, s. 173-174.

4 Ibidem, s. 174.

5 J. Makarewicz ilustrował tę zasadę następującymi przykładami: „Jeżeli w razie rozbicia się okrętu jedynym ratunkiem jest schronienie się do łodzi zapasowej, to dla ratowania siebie można odpychać tłoczących się, grożących przepełnieniem łodzi, nie wolno natomiast wyrzucać z łodzi osób tam znajdujących się dlatego, by zrobić miejsce dla innych. Wolno wyrywać pas ratunkowy dla siebie, nie wolno wyrywać pasa takiego dlatego, by udzielić go innej osobie. Wolno ratować z niebezpieczeństwa, ale nie wolno rozstrzygać o tym, która z dwu osób ma żyć, a która zginąć. Oczywiście wyjątek stanowić muszą rodzice, małżonkowie, bliższa rodzina występująca z pomocą dla swoich członków, mamy tu do czynienia z rozszerzonym (kwalifikowanym) egoizmem, który prawo uznać musi” (J. Makarewicz, Prawo karne ogólne... s. 174-175). 
niu. Było to nowe pojęcie prawne, którego źródeł należało szukać w nowożytnym rozwoju społecznym i w ogólnoludzkim solidaryzmie ${ }^{6}$.

Na stan wyższej konieczności mógł się skutecznie powołać tylko ten, kto sam nie doprowadził do krytycznej sytuacji. Z tego powodu Makarewicz sprzeciwiał się „przyznaniu przywileju wyższej konieczności” ludziom powołanym z tytułu wykonywanego zawodu do narażania się na niebezpieczeństwo. Dostrzegał natomiast $\mathrm{i}$ aprobował tendencje $\mathrm{w}$ nowożytnym ustawodawstwie do rozszerzania pojęcia wyższej konieczności w kierunku prawa konieczności (ratujący nie tylko nie popełnia czynu karalnego, ale nawet czynu bezprawnego; ma prawo do wykonania danej czynności). Rozszerzenie to miało doniosły charakter ze względu na ewentualne roszczenia cywilnoprawne. Czyn bezprawny, choć nie karalny, uzasadniał obowiązek odszkodowania. Natomiast uznanie przez ustawę działania w stanie wyższej konieczności za uprawnione zamykało drogę do dochodzenia roszczeń cywilnoprawnych. Makarewicz postulował przesunięcie takiego „prawa konieczności” do ustawy cywilnej i ograniczenie go do „przypadków szczególnie określonych"7.

Prawo francuskie łączyło pojęcie wyższej konieczności z działaniem przymusu nieodpornego, jako swoistą jego formę. Stan wyższej konieczności uważano za formę przymusu psychicznego, eliminującego możliwość wymagania od sprawcy, aby działał „ze swobodą myśli i kierowania swoimi czynami, niezbędną do uznania winy"8.

$\mathrm{Na}$ rozwiązaniu francuskim wzorowała się obowiązująca na ziemiach polskich austriacka ustawa karna o zbrodniach, występkach i przekroczeniach z dnia 27 maja 1852 r. Nie znała ona osobnego przepisu normującego stan wyższej konieczności, umieszczając odpowiednie postanowienia w § 2 pkt g), w myśl którego „zatem nie poczyta się za zbrodnię działania lub zaniechania, jeżeli dopuszczono się czynu wskutek nieodpornego przymusu lub w wykonaniu słusznej obrony koniecznej"”. Tym samym wpływ przymusu nieodpornego z $§ 2$ pkt g) nie dotyczył występków i wykroczeń. W stosunku do tych kategorii przestępstw można było zastosować § 264 uznający za okoliczności łagodzące między innymi działanie sprawcy „z bojaźni albo w przecenieniu autorytetu” (pkt d) lub „spowodowane koniecznością" (pkt f).

$\mathrm{W}$ przeciwieństwie do połowicznego rozwiązania przyjętego w austriackiej ustawie karnej stan wyższej konieczności ujęty został w sposób odrębny w dwóch

6 Ibidem, s. 175.

7 Ibidem, s. 175-176.

8 W. Makowski, Prawo karne. Część ogólna. Wykład porównawczy prawa karnego austriackiego, niemieckiego i rosyjskiego obowiqzujacego w Polsce, Warszawa 1920, s. 296.

9 Ustawa karna o zbrodniach, występkach i przekroczeniach z dnia 27 maja 1852 r. Cyt. za: J. Przeworski, Ustawa karna austriacka o zbrodniach, występkach i przekroczeniach z dnia 27 maja 1852 r. obowiqzujaca w okręgach Sadów Apelacyjnych w Krakowie $i$ we Lwowie oraz Sadu Okręgowego w Cieszynie, Warszawa 1924. 
pozostałych kodeksach karnych państw zaborczych, utrzymanych tymczasowo w mocy po odzyskaniu przez Polskę niepodległości w 1918 r. Niemiecki kodeks karny z 1871 r. stanowił w $§ 54$, że „nie ma przestępstwa, jeżeli czyn popełniono poza wypadkiem obrony koniecznej w niezawinionej a niedającej się inaczej uchylić wyższej konieczności, dla ocalenia sprawcy, albo którego spośród członków rodziny z obecnego niebezpieczeństwa dla ciała lub życia"10.

W niemieckim prawie stan wyższej konieczności uregulowany został nie tylko w kodeksie karnym, ale również w cywilnym (art. 228 i 904 B.G.B.) w zakresie prywatno-prawnych skutków podjętego w tych warunkach działania. Przepis art. 228 dotyczył uszkodzenia cudzej rzeczy „aby odwrócić grożące z jej strony niebezpieczeństwo od siebie albo innej osoby", uznając działanie takie za niezawierające cech przestępstwa, o ile „uszkodzenie lub zniszczenie rzeczy było potrzebne dla odwrócenia niebezpieczeństwa a szkoda nie pozostaje w rażącym stosunku do niebezpieczeństwa", i o ile sprawca sam nie zawinił przez spowodowanie niebezpieczeństwa; w przeciwnym razie miał on obowiązek naprawienia szkody. Z kolei art. 904 zobowiązywał właściciela, aby nie bronił obcym osobom oddziaływania na jego własność, jeżeli było to konieczne dla odwrócenia grożącego niebezpieczeństwa. W ten sposób B.G.B. szerzej i pełniej rozwijał sprawę wyższej konieczności, jej znaczenia i skutków prawnych. Zajmował stanowisko oparte na zasadzie równowagi obiektywnej zagrożonych i pokrzywdzonych interesów, domagając się, aby interes zagrożony, w obronie którego doszło do wyrządzenia szkody, znacznie przewyższał interes faktycznie poświęcony, i w tym upatrując usprawiedliwienia podjętego działania. W przeciwieństwie do niemieckiego kodeksu karnego nie był tu wymagany warunek, aby zagrożone dobro dotyczyło życia lub ciała sprawcy, albo jego bliskich. To unormowanie niemieckiego kodeksu cywilnego z 1896 r. uzupełniło i rozwinęło w myśl nowszych tendencji zasadę przyjęta jeszcze przez znacznie starszy kodeks karny z $1871 \mathrm{r}^{11}$

W rosyjskim kodeksie karnym z 1903 r. stan wyższej konieczności ujęty został w art. 46, który stanowił: „Nie będzie uważany za przestępstwo czyn, spełniony w celu uratowania życia własnego lub życia innej osoby przed niebezpieczeństwem, wynikłym wskutek groźby, przymusu bezprawnego lub innej przyczyny, niemożliwej do uniknięcia $\mathrm{w}$ tym samym czasie za pomocą innego środka. Nie będzie uważany za przestępstwo czyn, spełniony w celu uratowania zdrowia, wolności, czci niewieściej lub innego dobra osobistego lub majątkowego, własnego lub cudzego, przed niebezpieczeństwem wynikłym wskutek groźby, przymusu bezprawnego lub innej przyczyny, niemożliwej do uniknięcia w tym samym czasie za pomocą innego środka, o ile sprawca czynu miał dostateczną

10 Kodeks karny Rzeszy Niemieckiej z dnia 15 maja 1871 r.. Cyt. za: J. Kałużniacki, R.A. Leżański, Kodeks karny obowiqzujacy na ziemiach zachodnich Rzeczypospolitej Polskiej z uwzględnieniem najnowszego ustawodawstwa i orzecznictwa Sadu Najwyższego, wyd. IV, Warszawa-Poznań 1925.

11 W. Makowski, op. cit., s. 291-292. 
zasadę do uważania szkody, przezeń wyrządzonej, za nikłą w porównaniu z bronionym dobrem"12.

Rosyjski kodeks karny w art. 46 oddzielił zatem stan wyższej konieczności od przymusu nieodpornego i rozróżnił dwa typy tego stanu. W pierwszym działanie powinno być przedsięwzięte ,w celu uratowania życia własnego lub innej osoby przed niebezpieczeństwem wynikłym wskutek groźby, przymusu bezprawnego lub innej przyczyny, niemożliwej do uniknięcia w tym samym czasie za pomoca innego środka". W tym wypadku bezkarność, a zatem także uniknięcie odpowiedzialności cywilnej, nie było uzależnione od żadnych warunków dodatkowych; waga i znaczenie dobra poświęconego w celu ochrony życia nie były brane pod uwagę. Drugi ustęp przewidywał działanie, podjęte w tych samych warunkach, ale nie ze względu na zagrożenie życia, lecz ,w celu uratowania zdrowia, wolności, czci niewieściej lub innego dobra osobistego lub majątkowego, własnego lub cudzego". Dodatkowo, oprócz okoliczności charakteryzujących stan wyższej konieczności w poprzednim wypadku, dla uznania działania za pozbawionego charakteru przestępczego wymagano, żeby „sprawca miał dostateczną zasadę do uważania szkody, przezeń wyrządzonej, za nikłą w porównaniu z bronionym dobrem". W tym drugim przypadku zatem wzajemny stosunek przeciwstawnych interesów, bronionego i pokrzywdzonego, został wzięty pod uwagę, analogicznie jak w niemieckim ustawodawstwie cywilnym oraz w niektórych innych kodeksach karnych (norweskim, japońskim, projekcie szwajcarskim). Jednakże rosyjski kodek karny, w przeciwieństwie do innych, ocenił ten stosunek nie na podstawie obiektywnego zestawienia wartości konkurencyjnych dóbr, ale na podstawie subiektywnego mniemania sprawcy w chwili działania. Kodeks ten zawierał w rozbudowanym art. 46 także zastrzeżenie, że osoby zobowiązane z tytułu swojego stanowiska lub warunków, w jakich się znajdują, do narażenia się na niebezpieczeństwo, nie mogły powoływać się na stan wyższej konieczności. Niebezpieczeństwo ten stan powodujące musiało być rzeczywiste a nie domniemane lub urojone. Musiało być niemożliwe do odwrócenia innymi środkami niż pogwałcenie cudzego interesu. Sprawca tylko wtedy działał w stanie wyższej konieczności, jeśli możliwość wyboru dotyczyła alternatywy: interes broniony, albo interes cudzy. Jeżeli nadto miał do wyboru inne środki ratunkowe, nie sprowadzające krzywdy na cudze dobro, lub wręcz legalne, to powinien wybrać środki nikomu nie szkodzące. Jeżeli jednak takiego wyboru nie miał i musiał się zdecydować na naruszenie cudzych dóbr, wyrządzona szkoda nie powinna przekraczać koniecz-

12 Kodeks karny z 22 marca 1903 r. Cyt. za: W. Makowski, Kodeks karny obowiqzujacy tymczasowo w Rzeczypospolitej Polskiej na ziemiach b. zaboru rosyjskiego z dodaniem: przepisów przechodnich i ustaw, zmieniajacych i uzupetniajacych postanowienia karne kodeksu, odpowiednich przepisów Kodeksu Karnego Niemieckiego i Ustawy Karnej Austriackiej, obowiazujacych w pozostałych dzielnicach Rzeczypospolitej oraz Komentarza i orzeczeń Sąu Najwyższego, Warszawa 1921-1922. 
ności, w przeciwnym razie doszłoby do nadużycia stanu konieczności, a zatem działanie przestałoby być „konieczne”"13.

W instytucji uregulowanej w art. 46 rosyjskiego kodeksu karnego połączono zatem czynniki obiektywne i subiektywne, z których pierwsze służyły do stwierdzenia, czy stan wyższej konieczności istniał, czy działanie wynikało z tego stanu, odpowiadało mu i mieściło się $\mathrm{w}$ jego granicach; drugie - do usprawiedliwienia wniosku, że człowiek, działający pod wpływem takiej obiektywnej konieczności, nie może być uznany za winnego ani zasługującego na karę, ponieważ jego działanie jest skutkiem naturalnego reagowania psychiki na te obiektywne okoliczności, których usunąć, ani którym przeciwstawić się nie sposób ${ }^{14}$.

Konstrukcja stanu wyższej konieczności była także wnikliwie rozważana podczas obrad Sekcji Prawa Karnego Komisji Kodyfikacyjnej Rzeczypospolitej Polskiej w ramach prac nad projektem polskiego kodeksu karnego w celu wypracowania własnej, oryginalnej konstrukcji w miejsce rozwiązań prawnych znanych pozaborczym kodeksom karnym, wówczas już mocno przestarzałym albo wręcz anachronicznym.

W trakcie XXXVI posiedzenia Sekcji Prawa Karnego w dniu 9 czerwca 1921 r. Juliusz Makarewicz przedstawił referat, którego motywem przewodnim był stosunek obrony koniecznej do stanu wyższej konieczności. Referent wskazał na fundamentalne znaczenie różnicy między prawem do obrony różnych dóbr przed bezprawnym napadem lub grożącym niebezpieczeństwem a tylko bezkarnością działania sprawcy. W pierwszym przypadku działanie sprawcy nie spowoduje żadnych konsekwencji nie tylko w dziedzinie karnej, ale i cywilnej, w drugim - odpadnie kara, ale pozostaje bezprawność działania ze wszystkimi tego konsekwencjami. Napiętnowanie działania sprawcy, odpierającego napad lub chroniącego się przed niebezpieczeństwem, jako bezprawnego, wywołuje skutki nie tylko w dziedzinie cywilistycznej, ale także w dziedzinie karnej. Przyjmując, że działanie obronne napadniętego jest tylko bezkarne, uznać należy także bezkarność obrony napastnika wobec obrony napadniętego. Podał przykłady rozwiązań zawartych w różnych kodeksach, opowiadając się za stanowiskiem pośrednim zajmowanym przez projekty austriacki i szwajcarski. Projekty te zgodnie przyjmowały stan prawny przy obronie koniecznej a bezkarność przy wyższej konieczności. Argumentował, że już rozwój historyczny wskazuje na różnice w traktowaniu tych pojęć prawnych. Obrona konieczna jest bowiem tylko ograniczeniem dawnego prawa samodzielnego egzekwowania sprawiedliwości przez pokrzywdzonego, gdy tymczasem wyższa konieczność jest pojęciem „zwolna tylko się wybijającym iw nowszych czasach dopiero uzyskującym prawo obywatelstwa w dziedzinie okoliczności powodujących bezkarność”. Lwowski profesor przekonywał, że w ,interesie społecznym leży przyznawać wyjątkowe stanowisko każdemu, kto zwalcza

13 W. Makowski, Prawo karne. Część ogólna..., s. 292-295.

14 Ibidem, s. 295. 
bezprawie, nie leży jednak faworyzowanie zbyteczne tego, kto ratuje się przed niebezpieczeństwem". Uważał, że w tym drugim wypadku wystarczy przyznanie bezkarności ${ }^{15}$. Rozwiązanie przeciwne polegające na zrównaniu obu sytuacji na gruncie bezkarności byłoby niekorzystne dla osoby, która występując przeciwko bezprawiu, działa w pewnym stopniu jako przedstawiciel społeczeństwa. Zatarta zostałaby także różnica między obroną konieczną a bezkarnym przekroczeniem jej granic. $Z$ kolei przyznanie obu instytucjom charakteru prawnego stworzyłoby w praktyce trudne, życiowe sytuacje, np. niedopuszczalność obrony człowieka niewinnego przed zamachem na jego dobra ze strony innej osoby, która chciałaby ratować dobro własne przed grożącym niebezpieczeństwem cudzym kosztem. Napadnięty w ten sposób nie miałby ani możności bronienia się, ani nawet żądania odszkodowania. Można by próbować stworzyć konstrukcję wyższej konieczności wobec wyższej konieczności, co mogłoby skutkować trudnościami w praktyce ${ }^{16}$.

Po krótkiej dyskusji, wbrew stanowisku Makarewicza, popieranego przez Aleksandra Mogilnickiego, większością głosów przegłosowano zasadę zrównania stanu wyższej konieczności z obroną konieczną poprzez uznanie obu za okoliczności wyłączające bezprawność ${ }^{17}$.

Analizę problemu stanu wyższej konieczności, opartej na uwzględnieniu stanu psychicznego sprawcy, referent połączył z zagadnieniami pojawiającego się wówczas nowego pojęcia pomocy koniecznej, wynikającej z poczucia społecznej solidarności. Polegała ona na dopuszczeniu osoby trzeciej do ratowania zagrożonych dóbr, gdy dawniejsze kodyfikacje uwzględniały jedynie działanie w stanie wyższej konieczności samej osoby zagrożonej ${ }^{18}$. W głosowaniu przyjęto jednomyślnie uchwałe o „,potrzebie rozszerzenia wyższej konieczności w kierunku pomocy koniecznej"19. W toku dalszej dyskusji podjęto jeszcze jednomyślnie uchwałę, by nie wyliczać dóbr stanowiących przedmiot ochrony oraz podkreślającą proporcjonalność $\mathrm{w}$ stosunku do dóbr chronionego i poświęconego ${ }^{20}$. Natomiast pięcioma głosami przeciwko jednemu odrzucono instytucję przekroczenia granic wyższej konieczności. Referent przekonał bowiem większość uczestników dyskusji, że przekroczenie granic wyższej konieczności oznacza niedostosowanie się do warunków proporcjonalności dóbr lub subsydiarności wystapienia akcji ratowniczej w formie przedmiotowo karygodnej. Wskazal, że podstawą instytucji wyższej konieczności jest myśl przewodnia o konieczności poświęcenia do-

15 Protokół XXXVI-go posiedzenia Sekcji Prawa Karnego Materialnego Komisji Kodyfikacyjnej odbytego dnia 9. czerwca 1921 roku, [w:] Protokoły obrad, Komisja Kodyfikacyjna Rzeczypospolitej Polskiej, Wydział Karny, Sekcja Prawa Karnego (dalej: WK SPK), t. I, z. 3, Lwów 1922, s. $103-104$.

${ }^{16}$ Ibidem, s. 104.

17 A. Lityński, Wydziat Karny Komisji Kodyfikacyjnej II Rzeczypospolitej. Dzieje prac nad częściq ogólnq kodeksu karnego, Katowice 1991, s. 90.

18 Ibidem.

19 Protokót XXXVI-go posiedzenia Sekcji Prawa Karnego..., WK SPK, t. I, z. 3, s. 111.

20 Ibidem, s. 112. 
bra niższego rzędu dla ratowania dobra wyższego rzędu. O ile zaś nie dochowano warunku subsydiarności, powstaje sprzeczność logiczna, zachodzi brak konieczności. Z tych względów oświadczyć się należało przeciw faworyzowaniu przekroczenia granic wyższej konieczności, pozostawiając wypadki wyjątkowe sędziowskiemu wymiarowi kary. Makarewicz podkreślał, że praktyczne niebezpieczeństwo zachowania tej konstrukcji polega na tym, że może w społeczeństwie powstać tendencja do „bezceremonialnego szafowania obcymi dobrami dla ratowania własnych, nawet wtedy, kiedy można było ratować się inaczej (na drodze trudniejszej) i do rozpętania egoizmu i bezwzględności" ${ }^{21}$. Ponadto Makarewicz proponował ograniczenie instytucji pomocy koniecznej do ochrony obcego życia i zdrowia, ale wbrew jego stanowisku, popartemu przez Franciszka Nowodworskiego, Sekcja w uchwale opowiedziała się przeciwko wyliczaniu dóbr prawnych podlegających ochronie w ramach tej instytucji ${ }^{22}$.

Stanowisko wypracowane podczas obrad Sekcji zostało uwzględnione w art. 17-19 projektu wstępnego części ogólnej kodeksu karnego, przygotowanego przez Juliusza Makarewicza. Proponowany przez referenta art. 17 stanowił: „Nie ma przestępstwa, gdy sprawca działa dla uchylenia niebezpieczeństwa, grożącego jednemu z dóbr własnych, o ile niebezpieczeństwa nie można inaczej uchylić, a sprawca nie ma obowiązku narażenia się na niebezpieczeństwo"23. Z kolei art. 18 głosił: „Nie ma przestępstwa, gdy sprawca działa dla uchylenia niebezpieczeństwa, grożącego jednemu z dóbr innej osoby, o ile niebezpieczeństwa nie można inaczej uchylić, a sprawca nie działa wbrew woli zagrożonego"24. Natomiast zgodnie z art. 19 „dobro poświęcone $($ art. 17, 18) nie mogło przedstawiać wyższej wartości, niż dobro ocalone" 25 .

Prace nad projektem części ogólnej kodeksu karnego kontynuowano na posiedzeniach Sekcji w latach 1929-1930. Zostały one uwzględnione w projekcie kodeksu karnego w redakcji przyjętej w drugim czytaniu przez Sekcję Prawa Karnego Komisji Kodyfikacyjnej, którego druk ukończono w dniu 22 sierpnia 1930 r. ${ }^{26}$ Ujęty w art. 20 tego projektu stan wyższej konieczności w sposób dość istotny różnił się od konstrukcji zawartej w projekcie wstępnym części ogólnej kodeksu zredagowanym przez J. Makarewicza. Proponowany art. 20 stanowił w nowym brzmieniu: „Nie ulega karze, kto działa dla uchylenia bezpośredniego niebezpieczeństwa, grożącego dobru własnemu lub cudzemu, o ile niebezpieczeń-

21 Ibidem, s. 113.

22 Ibidem, s. 114.

23 J. Makarewicz, Ustawa karna (część ogólna). Projekt wstępny, odbitka z czasopisma „Przegląd Prawa i Administracji, z. 4-6, Lwów 1922.

24 Ibidem.

25 Ibidem.

26 Projekt kodeksu karnego, w redakcji przyjętej $w$ drugim czytaniu przez Sekcje Prawa Karnego Komisji Kodyfikacyjnej R.P., Komisja Kodyfikacyjna Rzeczypospolitej Polskiej, Sekcja Prawa Karnego (dalej: SPK), t. V, z. 2, Warszawa 1930. 
stwa nie może inaczej uniknąć (§ 1). Nie działa w stanie wyższej konieczności, kto ma szczególny obowiązek narażenia się na niebezpieczeństwo (§ 2). Dobro poświęcone nie może przedstawiać wartości oczywiście większej, niż dobro ocalone (§ 3). W razie przekroczenia granic wyższej konieczności sąd może zastosować nadzwyczajne złagodzenie kary (§ 4)"27.

Polska konstrukcja stanu wyższej konieczności była najbardziej zbliżona do nowoczesnych rozwiązań znanych rosyjskiemu kodeksowi karnemu z 1903 r. a pod względem techniki legislacyjnej przewyższała unormowania zawarte we wszystkich kodeksach pozaborczych obowiązujących w tym czasie na ziemiach polskich. Austriacka ustawa karna z 1852 r. upoważniała sędziego jedynie do zastosowania $\mathrm{w}$ odpowiednich wypadkach przepisu o przymusie nieodpornym, co skutkowało bardzo wąskim ujęciem problemu. Z kolei niemiecki kodeks karny z 1871 r. dopuszczał bezkarność z tego tytułu tylko w odniesieniu do ochrony zdrowia i życia własnego lub osób bliskich. $Z$ jednej strony rozszerzał zatem zakres instytucji przez wprowadzenie jako tytułu bezkarności ochrony osób bliskich, ale z drugiej strony zawężał rodzaj chronionych dóbr tylko do zdrowia i życia. W porównaniu z tymi regulacjami stanowisko nowoczesne zajmował rosyjski kodeks karny, ponieważ pozwalał chronić przed niebezpieczeństwem nawet dobra osób obcych, a tym samym instytucja wyższej konieczności obejmowała tu także instytucję pomocy koniecznej. Ponadto zasadę proporcjonalności kodeks rosyjski zastrzegał tylko do ochrony dóbr innych niż życie. Natomiast polski projekt połączył w jednym przepisie stan wyższej konieczności i pomoc konieczną, konstruując syntetyczną instytucję ochrony przed niebezpieczeństwem jakiegokolwiek i czyjegokolwiek dobra. Projekt polski zastrzegł jednak, że działanie może być bezkarne tylko wtedy, gdy było niezbędne, bo niebezpieczeństwa nie można było inaczej uniknąc ${ }^{28}$. Projekt, w odróżnieniu od kodeksu niemieckiego i rosyjskiego nie wymagał, żeby niebezpieczeństwo wynikało z groźby bezprawnej. Jego źródło uznano za kwestię drugorzędną; mogła to być równie dobrze groźba bezprawna ze strony człowieka (np. groźba zabójstwa), jak również klęska żywiołowa (pożar, powódź, itp.). Zasady proporcjonalności dóbr projekt także nie przeprowadził w sposób tak rygorystyczny, jak wcześniejszy, rosyjski kodeks karny z 1903 r., który żądał (poza zagrożeniem życia), żeby szkoda wyrządzona była $\mathrm{w}$ ocenie sprawcy nikła w porównaniu z chronionym dobrem. Polski projekt wymagał jedynie, żeby dobro poświęcone w przekonaniu sprawcy nie przedstawiało wartości oczywiście wyższej niż dobro ocalone. Przepisy o bezkarności takiego działania nie miały jednak zastosowania do osób wykonujących zawody, których istotą było narażanie się na niebezpieczeństwo ${ }^{29}$.

27 Ibidem, s. 10.

28 Projekt kodeksu karnego, $w$ redakcji przyjętej $w$ drugim czytaniu przez Sekcje Prawa Karnego Komisji Kodyfikacyjnej R.P. Uzasadnienie części ogólnej, SPK, t. V, z. 3, Warszawa 1930, s. 33-34.

29 Ibidem, s. 34-35. 
Polski projekt w art. $20 \S 3$ wprowadził - wbrew stanowisku Makarewicza popartym przez Sekcję w trakcie prac nad częścią ogólną — instytucję przekroczenia stanu wyższej konieczności, gdy nie zachowano zasady proporcjonalności dóbr (np. dla ratowania mienia poświęcono zdrowie lub życie). Nie miała ona jednak zastosowania, jeśli stan wyższej konieczności w ogóle nie zaistniał, a zatem, gdy niebezpieczeństwo nie było bezpośrednie, albo gdy można było zagrożone dobro ratować w inny sposób niż przez poświęcenie innego dobra. Wówczas nie było to bowiem przekroczenie stanu wyższej konieczności, ale zwykły czyn karalny. „Przekroczenie granic wyższej konieczności nie miało znaczenia innego, jak uzasadnienie (§ 4) możliwości stosowania nadzwyczajnego złagodzenia kary (a zatem zejścia niżej ustawowego minimum, zastosowania innego środka karnego)"30.

Na uwagę zasługuje także przeciwstawienie wyższej konieczności - obronie koniecznej, ponieważ w redakcji ustalonej w drugim czytaniu projekt $\mathrm{w}$ stosunku do wyższej konieczności zawierał sformułowanie „nie ulega karze”, zaś w przypadku obrony koniecznej użyto frazy „nie popełnia przestępstwa”. Zwrócono $\mathrm{w}$ ten sposób uwagę — zgodnie z propozycją J. Makarewicza — na odmienne znaczenie prawne obu instytucji $\mathrm{w}$ zakresie skutków na gruncie prawa cywilnego, które „mogło wyciągnąć wnioski z faktu, że wyższa konieczność nie wytwarza sytuacji nadającej działaniu charakter prawny a jedynie tylko uwalnia działającego od kary"31.

Ujęcie stanu wyższej konieczności, zaproponowane w drugim czytaniu, utrzymane zostało $\mathrm{w}$ projekcie kodeksu karnego w redakcji przyjętej w trzecim czytaniu (art. 20) ${ }^{32}$. Nieznacznie zmodyfikowano jedynie $\S 1$, zamieniając sformułowanie „,[...] o ile niebezpieczeństwa nie może inaczej uniknąć” na ,[...] jeśli niebezpieczeństwa nie można inaczej uniknąć".

Była to ostateczna wersja konstrukcji stanu wyższej konieczności zawartej w projekcie kodeksu karnego przekazanym Ministrowi Sprawiedliwości w drugiej połowie września $1931 \mathrm{r}^{33}$ Drobną zmianę redakcyjną wprowadzono jeszcze podczas dalszych prac legislacyjnych ${ }^{34}-\mathrm{w} \S 1$ sformułowanie „Nie ulega ka-

\section{Ibidem, s. 35.}

31 Ibidem.

32 Projekt kodeksu karnego, $w$ redakcji przyjętej $w$ trzecim czytaniu przez Sekcje Prawa Karnego Komisji Kodyfikacyjnej R.P., SPK, t. V, z. 5, Warszawa 1931, s. 6.

33 J. Jamontt, E.S. Rappaport, R. Lemkin, Kodeks karny r. 1932 z dostosowanymi do kodeksu tezami z orzeczeń Sadu Najwyższego, odpowiednimi ustępami uzasadnienia projektu Komisji Kodyfikacyjnej oraz ze skorowidzem, Warszawa 1932, s. XV.

${ }^{34}$ Do oceny projektu powołana została Komisja Ministerialna w składzie: Podsekretarz Stanu S. Sieczkowski (Przewodniczący) oraz L. Bekerman, J. Gumiński, J. Jamontt, W. Kuczyński, S. Lubodziecki, W. de Michelis i A. Miller. Pracowała ona do marca 1932 r. W dniach 9-10 marca 1932 r. Minister Sprawiedliwości C. Michałowski zorganizował specjalną naradę z udziałem części członków Komisji Ministerialnej oraz nie uczestniczących wcześniej w jej posiedzeniach Sekretarzem Generalnym Komisji Kodyfikacyjnej S.E. Rappaportem i głównymi referentami, J. Makarewiczem i W. Makowskim. W trakcie wspólnych narad ustalono ostateczny tekst projektu kodeksu karnego 
rze [...]” zastapione zostało przez „Nie podlega karze [...]”. Ponadto w związku z modyfikacją innych przepisów projektu ustalono także nową numerację artykutu (,22" w miejsce „20").

Ostatecznie art. 22 k.k. otrzymał zatem następujące brzmienie: „Nie podlega karze, kto działa w celu uchylenia bezpośredniego niebezpieczeństwa grożącego dobru własnemu lub cudzemu, jeżeli niebezpieczeństwa nie można inaczej uniknąć (§ 1). Nie działa w stanie wyższej konieczności, kto ma szczególny obowiązek narażenia się na niebezpieczeństwo (§ 2). Dobro poświęcone nie może przedstawiać wartości oczywiście większej niż dobro chronione (§ 3). W razie przekroczenia granic wyższej konieczności sąd może zastosować nadzwyczajne złagodzenie kary" ${ }^{\prime 3}$.

Po wejściu w życie kodeksu karnego konstrukcja stanu wyższej konieczności wypracowana przez Sekcję Prawa Karnego Komisji Kodyfikacyjnej wzbudzała pewne wątpliwości interpretacyjne, które znalazły odzwierciedlenie w wykładni tego artykułu w orzecznictwie Sądu Najwyższego.

W wyroku z dnia 12 listopada 1934 r. Sąd Najwyższy stwierdził, że stan wyższej konieczności, w odróżnieniu od stanu obrony koniecznej, zachodzi nie wtedy, gdy działa się w obronie prawa przed zamachem bezprawnym na nie, a wtedy, gdy w celu uchylenia grożącego niebezpieczeństwa, narusza się dobro innej osoby, niczyjego prawa nie naruszającej ${ }^{36}$.

Sąd Najwyższy zajął także stanowisko, że istotą stanu wyższej konieczności (art. 22 k.k.) jest rzeczywista kolizja dóbr, z której wyjście polegać może jedynie na uratowaniu jednego dobra drogą poświęcenia innego, przy czym przepis art. 22 k.k. nie zawierał ograniczeń co do rodzaju i charakteru dóbr zagrożonych i poświęconych, oraz nie czynił różnicy między dobrem własnym działającego a dobrem cudzym (pomoc konieczna). Przepis art. 22 k.k. nie wymagał stosunkowości dóbr i proporcjonalnej ich wartości, i tylko wtedy, gdy dobro poświęcone przedstawiało wartość oczywiście większą (a nie zwyczajnie i normalnie większą), mogła być mowa o przekroczeniu granic wyższej konieczności ${ }^{37}$. Sąd

w postaci, w której Minister Sprawiedliwości zamierzał wprowadzić go w życie. W marcu-maju 1932 r. Ministerstwo Sprawiedliwości konsultowało projekt jeszcze z przedstawicielami innych, zainteresowanych resortów. Dopiero w końcu maja 1932 r. projekt kodeksu karnego został przedłożony Radzie Ministrów. Następnie, na podstawie art. 44 ust. 6 ustawy z dnia 17 marca 1921 r. konstytucja Rzeczypospolitej Polskiej (Dz.U. RP z 1921 r. Nr 44, poz. 267 z późn. zm.) i art. 1 lit. a ustawy z dnia 17 marca 1932 r. o upoważnieniu Prezydenta Rzeczypospolitej do wydawania rozporządzeń z mocą ustawy (Dz.U. RP z 1932 r. Nr 22, poz. 105), Prezydent Rzeczypospolitej podpisał w dniu 11 lipca 1932 r. rozporządzenie z mocą ustawy, ustalając termin wejścia w życie kodeksu karnego na dzień 1 września 1932 r. (J. Jamontt, E.S. Rappaport, R. Lemkin, op. cit., s. XVII-XIX).

35 Rozporządzenie Prezydenta Rzeczypospolitej z dnia 11 lipca 1932 r. Kodeks karny (Dz.U. RP z 1932 r. Nr 60, poz. 571 z późn. zm.).

36 Wyrok SN z 12 listopada 1934 r. — I K 740/340, OSN(K) 1935/6/217.

37 Wyrok SN z 17 kwietnia 1935 r. — II K 198/35, OSN(K) 1935/12/504. 
Najwyższy rozstrzygnął także, że obawa ewentualnie możliwych niekorzystnych skutków niewykonania przez oskarżonego poleceń przełożonych, sama przez się nie uzasadnia zastosowania przepisu $\S 1$ art. 22 k.k. Niezbędnym bowiem warunkiem uznania, że czyn został dokonany w stanie wyższej konieczności jest, aby zmierzał on do uchylenia bezpośrednio grożącego niebezpieczeństwa, nie wystarcza natomiast sama tylko możliwość, że niebezpieczeństwo takie może nastapic ${ }^{38}$.

W wyroku z dnia 17 kwietnia 1936 r. Sąd Najwyższy nie pozostawił wątpliwości, że stan wyższej konieczności przewidziany w art. 22 k.k. wtedy jedynie może mieć miejsce, gdy sprawca działa w celu uchylenia bezpośredniego niebezpieczeństwa, które nie wynikało z winy osób, przeciwko którym skierowane zostało występne działanie ${ }^{39}$. Stan wyższej konieczności z art. 22 k. k., polegający na uchylaniu bezpośredniego niebezpieczeństwa w postaci gróźb, które mogły być w każdej chwili urzeczywistnione, mógł trwać przez czas dłuższy, niedający się bliżej teoretycznie określić ${ }^{40}$.

W wyroku z dnia 13 stycznia 1938 r. Sąd Najwyższy zajął z kolei stanowisko, że stan wyższej konieczności zachodzi wtedy, gdy niebezpieczeństwo grożące nie jest skutkiem zawinionego działania sprawcy przestępstwa, nie ma natomiast miejsca wtedy, gdy przestępstwo zostaje dokonane w tym celu, aby uchronić się od odpowiedzialności grożącej za popełnienie innego przestępstwa czy wykroczenia służbowego ${ }^{41}$. Według Sądu Najwyższego stan wyższej konieczności mógł zaistnieć jedynie w przypadku kolizji interesów znajdujących się pod ochroną prawa. Interes dłużnika, przeciwko któremu prowadzono postępowanie egzekucyjne, był chroniony przez prawo jedynie $\mathrm{w}$ granicach ustalonych przepisami rozdziału $\mathrm{V}$ księgi I części II k.p.c. Stąd popełnienie przestępstwa w obronie interesu dhużnika, nie chronionego przepisami k.p.c., nie podpadało pod przepisy o stanie wyższej konieczności ${ }^{42}$. Orzekł także Sąd Najwyższy, że działanie w celu uniknięcia istniejącej w przeświadczeniu sprawcy możliwości nastapienia niekorzystnych dla niego skutków, nie było działaniem ani pod przymusem fizycznym (art. 19 k.k.), ani też w stanie wyższej konieczności (art. 22 k.k.) ${ }^{43}$. Sąd Najwyższy zdecydowanie zatem sprzeciwił się próbom wykorzysta instytucji stanu wyższej konieczności poza granicami określonymi w art. 22 k.k.

Konstrukcja stanu wyższej konieczności wypracowana przez Sekcję Prawa Karnego Komisji Kodyfikacyjnej i przyjęta w polskim kodeksie karnym była zatem rozwiązaniem nowoczesnym, szczególnie w porównaniu z przepisami zawartymi w pozaborczych kodeksach karnych. Sformułowana została w sposób

\footnotetext{
38 Wyrok SN z 23 maja 1935 r. - II K 383/35, OSN(K) 1936/1/22.

39 Wyrok SN z 17 kwietnia 1936 r. - I K 1490/35, OSN(K)1936/11/401.

40 Wyrok SN z 21 stycznia 1937 r. - II K 1444/36, OSN(K) 1937/8/219.

41 Wyrok SN z 13 stycznia 1938 r. - II 1477/37, OSN(K) 1938/7/169.

42 Wyrok SN z 3 marca 1938 r. - II K 1762/37, OSN(K) 1938/9/123.

43 Wyrok SN z 17 czerwca 1938 r. - II K 119/38, OSN(K) 1939/3/59.
} 
syntetyczny, jasny i przejrzysty, stanowiąc wzór dla analogicznych instytucji unormowanych w dwóch kolejnych, polskich kodeksach karnych.

\section{Bibliografia}

\section{Wykaz aktów prawnych, projektów oraz orzeczeń Sądu Najwyższego}

Protokót XXXVI-go posiedzenia Sekcji Prawa Karnego Materialnego Komisji Kodyfikacyjnej odbytego dnia 9. czerwca 1921 roku, [w:] Protokoty obrad, Komisja Kodyfikacyjna Rzeczypospolitej Polskiej, Wydział Karny, Sekcja Prawa Karnego, t. I, z. 3, Lwów 1922, s. 95-114.

Makarewicz J., Ustawa karna (część ogólna). Projekt wstępny, odbitka z czasopisma „Przegląd Prawa i Administracji, z. 4-6, Lwów 1922.

Projekt kodeksu karnego, w redakcji przyjętej w drugim czytaniu przez Sekcję Prawa Karnego Komisji Kodyfikacyjnej R.P., Komisja Kodyfikacyjna Rzeczypospolitej Polskiej, Sekcja Prawa Karnego, t. V, z. 2, Warszawa 1930.

Projekt kodeksu karnego, w redakcji przyjętej w drugim czytaniu przez Sekcję Prawa Karnego Komisji Kodyfikacyjnej R.P. Uzasadnienie części ogólnej, Sekcja Prawa Karnego, t. V, z. 3, Warszawa 1930.

Projekt kodeksu karnego, w redakcji przyjętej w trzecim czytaniu przez Sekcję Prawa Karnego Komisji Kodyfikacyjnej R.P., Sekcja Prawa Karnego, t. V, z. 5, Warszawa 1931.

Rozporządzenie Prezydenta Rzeczypospolitej z dnia 11 lipca 1932 r. Kodeks karny (Dz.U. RP z 1932 r. Nr 60, poz. 571).

Wyrok SN z 12 listopada 1934 r. — I K 740/340, OSN(K) 1935/6/217.

Wyrok SN z 17 kwietnia 1935 r. — II K 198/35, OSN(K) 1935/12/504.

Wyrok SN z 23 maja 1935 r. - II K 383/35, OSN(K) 1936/1/22.

Wyrok SN z 17 kwietnia 1936 r. — I K 1490/35, OSN(K)1936/11/401.

Wyrok SN z 21 stycznia 1937 r. — II K 1444/36, OSN(K) 1937/8/219.

Wyrok SN z 13 stycznia 1938 r. — II 1477/37, OSN(K) 1938/7/169.

Wyrok SN z 3 marca 1938 r. - II K 1762/37, OSN(K) 1938/9/123.

Wyrok SN z 17 czerwca 1938 r. — II K 119/38, OSN(K) 1939/3/59.

\section{Literatura}

Borowski W.M., Zasady prawa karnego, t. I. Część ogólna, Poznań 1922.

Jamontt J., Rappaport E.S., Lemkin R., Kodeks karny r. 1932 z dostosowanymi do kodeksu tezami z orzeczeń Sadu Najwyższego, odpowiednimi ustępami uzasadnienia projektu Komisji Kodyfikacyjnej oraz ze skorowidzem, Warszawa 1932.

Kałużniacki J., Leżański R.A., Kodeks karny obowiqzujacy na ziemiach zachodnich Rzeczypospolitej Polskiej z uwzględnieniem najnowszego ustawodawstwa i orzecznictwa Sadu Najwyższego, wyd. IV, Warszawa-Poznań 1925.

Lityński A., Wydział Karny Komisji Kodyfikacyjnej II Rzeczypospolitej. Dzieje prac nad częścia ogólnq kodeksu karnego, Katowice 1991.

Makarewicz J., Prawo karne ogólne, Kraków 1914.

Prawo 321, 2016

(C) for this edition by CNS 
Makowski W., Kodeks karny obowiqzujacy tymczasowo w Rzeczypospolitej Polskiej na ziemiach b. zaboru rosyjskiego z dodaniem: przepisów przechodnich i ustaw, zmieniajacych i uzupetniajacych postanowienia karne kodeksu, odpowiednich przepisów Kodeksu Karnego Niemieckiego $i$ Ustawy Karnej Austriackiej, obowiazujacych w pozostatych dzielnicach Rzeczypospolitej oraz Komentarza i orzeczeń Sqdu Najwyższego, Warszawa 1921-1922.

Makowski W., Prawo karne. Część ogólna. Wykład porównawczy prawa karnego austriackiego, niemieckiego i rosyjskiego obowiqzujacego w Polsce, Warszawa 1920.

Przeworski J., Ustawa karna austriacka o zbrodniach, występkach i przekroczeniach z dnia 27 maja 1852 r. obowiqzujaca $w$ okręgach Sqdów Apelacyjnych w Krakowie $i$ we Lwowie oraz Sadu Okręgowego w Cieszynie, Warszawa 1924.

\title{
State of necessity in the draft Polish Criminal Code of 1932
}

\author{
Summary
}

The article is devoted to state of necessity in the draft Polish Criminal Code of 1932. The author discusses the origins of the construct, its place in the criminal codes in force in Poland, the work of the Criminal Law Section of the Codification Commission of the Polish Republic, and the legal structure of the regulations in the draft Polish Criminal Code.

He demonstrates that the state of necessity in the draft Polish Criminal Code of 1932 was shaped by in-depth reflection in the Criminal Law Section taking into account the European doctrine of law and European legislation. When it comes to the state of necessity, the draft Polish Criminal Code sought to apply to it the latest solutions known from the existing legislation.

Keywords: Codification Commission, draft, Criminal Code, state of necessity, Juliusz Makarewicz

\section{Die Konstruktion des Notstandes in dem Entwurf des polnischen Strafgesetzbuches aus dem Jahre 1932}

Zusammenfassung

Die Bearbeitung betrifft die Konstruktion des Notstandes in dem Entwurf des polnischen Strafgesetzbuches aus dem Jahre 1932. Vorgestellt wurde die Genese dieser Institution, ihre Regulierung in den auf polnischem Gebiet geltenden Strafgesetzbüchern, der Verlauf der Arbeiten im Rahmen der Sektion Strafrecht in der Kodifikationskommission der Republik Polen und die rechtliche Konstruktion der Institution in dem Entwurf des polnischen Strafgesetzbuches.

Es wurde gezeigt, dass der Notstand in dem Entwurf des polnischen Strafgesetzbuches aus dem Jahre 1932 seine Gestalt aufgrund vertiefter Überlegungen im Rahmen der Sektion Strafrecht nahm, die das Werk der europäischen Rechtsdoktrin und der europäischen Gesetzgebung berücksichtigten. Das charakteristische Merkmal des polnischen Entwurfes des Strafgesetzbuches im Bezug auf diese Institution war die Bestrebung, sie unter Beachtung der neusten Entwicklungen auf Grund der damals bekannten Gesetzgebung zu gestalten.

Schlüsselworte: Kodifikationskommission, Entwurf, Strafgesetzbuch, Notstand, Juliusz Makarewicz

Prawo 321, 2016

(C) for this edition by CNS 